\title{
PREDICTING CONSUMER PERCEPTION AND ITS IMPACT ON PURCHASE INTENTION FOR RESIDENTIAL PROPERTY MARKET
}

\author{
Jeremy Tsang Tsun Hoe ${ }^{1}$, Omkar Dastane ${ }^{2}$, Karthik Selvaraj ${ }^{3}$ \\ ${ }^{1,3}$ Lord Ashcroft International Business School, Anglia Ruskin University, Cambridge, \\ United Kingdom \\ ${ }^{2}$ School of Accounting \& Business Management, FTMSGlobal Malaysia, Cyberjaya, Malaysia \\ Semarak Api, Cyber 4, Cyberjaya, Selangor, Malaysia. \\ *Corresponding Email: omkar.dastane@gmail.com
}

\begin{abstract}
The objective of this study is to investigate the effects of customer perceived value on customer purchase intention in the residential property market in Malaysia. The research proposes extension of Seth et al., 1991 model for property market by including relational aspect of the value as an added new parameter. Explanatory research design approach is used in this study with primary data collection through questionnaire survey of 172 respondents using convenience sampling method. The collected data and results are then analysed using SPSS 22 for Demographic analysis, Normality and Reliability test, Data Distribution. Finally, Pearson correlation analysis and Regression test is done to find the correlation between any two variables and relationship among the variables. The analysis indicated overall positive significant relationship with epistemic value being the highest among all. Regression analysis indicated functional value, social value, relational value, conditional value, and epistemic value shows positive significant effects on customer purchase intention while emotional value shows positive insignificant effect on customer purchase intention. The research is useful for marketers and researchers to understand perceived value based customer purchase intention for residential property sector among Malaysians and the tested model will be of great utility to property developers to devise appropriate value proposition based on consumer perceived value.
\end{abstract}

Keywords: Perceived Value, Purchase Intention, Residential Property, Theory of Consumption Value, DOI: https://doi.org/10.30880/jtmb.2018.05.02.007 


\subsection{Introduction}

The development of housing and real estate contribute to a major part of a country's economic development and gross domestic product (GDP) (Kong, et al., 2015). With the majority of the residential property, ranging from low to high end, developed by the private sectors nowadays, there are fierce competition among property developers as well as adverse factors such as economic downturn, rising interest rate, inflation rate, political volatility that affect the housing market. Therefore, housing developers have no choice but to enhance their competitiveness in order to survive in the property market, particularly in the residential sector. It is vital for perceived value to be considered in the process of decision making of consumers in purchasing products or services. Assessment will be made to a products' perceived value received by customers according to individual judgement and the sacrifice to offer in return (Monroe, 1985). Hence, if developers did not satisfy customers' purchase intention, a decline of market share will be experienced as customer perceived value influences consumers' purchase intention.

Previously, there are few studies done on the effect of customer perceived value on customer purchase intention in the property industry context (Lundgren, 2013; ; Lima, et al., 2009; Karna, et al., 2004; Karna, 2014; Yang \& Zhu, 2006). While there are several previous researches done in analysing the property or construction markets and industries in countries such as Thailand, Brazil, China, Australia etc. (Karna, et al., 2004; Lima, et al., 2009; Lundgren, 2013; Yang \& Zhu, 2006), there is insufficient study, or none in this case, to support the analyses of the Malaysian housing properties market in terms of the impact customer perceived value on customer purchase intention. As mentioned earlier, the economic and nation's development is greatly driven by housing real estate development and hence customer purchase intention plays an important role in assuring customer loyalty by analysis of customer perceived value. According to the National Property Information Centre of Malaysia (NAPIC, 2017), there are total of RM 10 billion worth of housing properties left unsold for the first quarter of 2017 in Malaysia which exclude serviced apartments which are under the category of commercial properties. It is reported that the housing properties overhang has increased $30.7 \%$ at the end of 2016 and the property transaction volume has greatly deteriorated by $5.4 \%$ in the first quarter of 2017. The overhang value has exceeded $100 \%$ from RM 4.4 billion to RM 10 billion from 2008 to first quarter of 2017 (over 10 years) (Thean, 2017) which indicates that the overhang value has significantly increased despite the declining number of residential properties launching. This phenomenon suggests that nowadays housing properties buyers or customers have a lot of precautions and considerations prior to purchasing houses which can be due to inflation, increased living cost, job insecurities, economic downturn etc. in the recent years. The other factors causing such phenomena includes locational convenience, availability of basic amenities/facilities, planning, difficulties in down payment settlement etc. (Thean, 2017).

The economic development in Malaysia has seen the demand for residential properties in an upward trend as the appreciation of housing price is significant in Malaysia (Ong, 2013). The overall performance of economy (including gross domestic product, employment rate, petrol prices etc.) directly impacts the value of housing properties and the current situation of Malaysian economy is worsening with ringgit getting weaker, increasing cost of living and property price (Lim, 2016). The increasing housing properties price coupled with inflation has led to a situation where most people could not cope with the high property price. The housing property market drives the Malaysian economy. Hence, there exists a need to further investigate the Malaysian property market in terms of factors affecting the market, especially in the customer perceived value's effect in customer purchase intention context. It is confirmed in the Property Market Report 2016 that the overall property market in Malaysia has recorded a decline of $11.5 \%$ in volume and 3\% decline in value in 2016 where residential properties, located out of vicinity of public transportation such as MRT or LRT, experienced reduce rental rates and with new property launches decreased $9.8 \%$, along with poor sales performance. On the other hand, vacancy rate has increased for the office and retail properties especially in Kuala Lumpur and Selangor areas with 16\% increase (for office) and $11.9 \%$ (for retail) in 2016 (Mahalingam, 2017). 
It is projected that the property market will suffer terribly by 2018 and leads to market crash due to the incapacity of consumers to own home. According to the statistic from the minister of finance, the number of completed residential properties left unsold in the first half of 2017 has experienced inclination of as much as $40 \%$ equivalent to 20,807 units compared to the first half of 2016 which worth RM12.26 billion with condominiums and apartments made up RM 500,000 of the total cost (Kaur, 2017). It is said that the RM12.26 billion worth of unsold units comes from the primary market including new property launchings by developers and subsequently the values of houses in the secondary market (sub-sales) is estimated to be RM4 billion with more foreclosures by banks projected due to weak demand (Kaur, 2017). This paper analyses the impact of customer perceived value on customer purchase intention and this study provides guideline for companies in distinguishing the key variables that influence customer purchase intention which would ultimately come up with effective methods to achieve customers' demands. This will, in return, improves customer purchase intention undoubtedly in addition to customer loyalty and retention. Through this study, housing developers can identify the key customer perceived value and distinguish present issues based on current market to develop remedial action plans in rectifying them, resulting in higher customer purchase intention in the housing properties market.

Furthermore, the purpose of this research is to assist housing developers to understand the current and future housing trend in order to improve or develop better policies. It is essential and imperative for any business corporation to come up with customer focused tactics through strategic transformations (Roy \& Cochrane, 1999). In general, requirement for customer purchase intention (from the relevant customer perceived value) drives housing developers in creating houses with greater purchase intention to the end users leading to higher yield of customer loyalty and profitability as well as improved standard of living (Yeung, et al., 2002), especially in the context of Malaysian residential property market. This research aims to seek focus on these key research objectives: To study the impact/effect of perceived functional value on customer purchase intention in property industry. To study the impact/effect of perceived social value on customer purchase intention in property industry. To study the impact/effect of perceived emotional value on customer purchase intention in property industry. To study the impact/effect of perceived relational value on customer purchase intention in property industry. To study the impact/effect of perceived conditional value on customer purchase intention in property industry. To study the impact/effect of perceived epistemic value on customer purchase intention in property industry.

\subsection{Literature Review}

\subsection{Definition of Key Concepts \& Terms}

Customer Perceived Value (CPV): CPV is a consumer's general evaluation of the value of a product or service which is based on an individual's personal assessment of benefits and worth and this is subject to individuals' opinions (Zeithaml, 1988). On the other hand, Sheth, et al. (1991) designed a conceptual model of five value types which explains the influence of the selection situation of customers in buying behaviour. In addition, Holbrook (1996) came up with the theory of perceived value which includes the relationship between customers and the service or products against the benefits received by them in exchange for the money expended (Zeithaml, 1988). Customer perceived value is known as the perceived assessment of customers of the product quality against the benefits received upon using, in either assisting or denying the customers' intentions when using the products (Woodruff, 1997). Fascinatingly, an excerpt from Yamamoto (2007)'s definition about customer value equals to the discrepancies between values acquired by consumers via owning or using the product against the price to own the product.

Customer Satisfaction: Customer satisfaction is how consumers evaluate these products or service in terms of fulfillment of individual's needs and expectations when consuming or using products or services (Oliver, 1997; Oliver, 1992). This findings matches to the study by Halstead, et al. (1994) where it is discovered that customer satisfaction is known as the transaction-specific response and this stems from the comparison between perceived standards or expectation and certain products 
or services during consumption. Subsequently, Mano \& Oliver (1993) defines customer satisfaction as the evaluation and assessment of products or services after purchasing or consuming by customers. On the other hand, customer satisfaction is said to be the state of cognition for received rewards in exchange for the price sacrificed by the customers (Howard \& Sheth, 1969). Likewise, Ilieska (2009) conducted a study where customer satisfaction is regarded as the feelings of customers, either happiness or discontent, because of the difference between the quality of products or services against the expectations.

Purchase Intention: Customer purchase intention is a type of decision which assess the reason customers select and purchase a certain brand (Younus, et al., 2015) and customers' preference in purchasing a product or service. Tung \& Albert (1994) claimed that the greater the perceived value, the higher the customer purchase intention. Moreover, customer purchase intention is originated from each individual's perceived benefits and values acquisition which forms the vital source in predicting customer purchase behavior and intention (Chi, et al., 2011). Furthermore, purchase intention is defined as a common measurement of effectiveness in predicting customer puchasing behavior (Kotler, 2000) and it indicates customers' preference in purchasing a product or service which satisfies their needs or opinions / perception towards the product or service.

\subsection{Critical Review of Key Models and Theories}

SHETH, ET AL. (1991) - Theory of Consumption Value: One of the most up to date models that explain consumers' purchase behavior is the consumption values model developed by Sheth (1991a). Developed out of the effects of personal values on consumer behaviour, consumption values (Sheth et al., 1991) is an important model that shows why a product is preferred. Usefulness, strength of this theory is its simplicity as it is simpler in comprehending customer perceived value through searching its dimensions (Aulia, et al., 2016) and this model is excellent in assessing the diverse traits and attributes of products through exploring customers' judgement (Animashaun, et al., 2016). Criticism, However, it is also similarly vital for consumption values in terms of preferences of product (Candan, et al., 2013) and this theory merely show that the choice made by customers as well as merely dealing with voluntary and logical selections instead (Animashaun, et al., 2016). Hence, the uncommon functionality needs to be simplified (Animashaun, et al., 2016).

ZEITHAML (1988) - Model of Four Types of Perceived Value: Zeithaml (1988) asserts that the perceived quality is regarded as benefits and that perceived price is considered as sacrifices for particular products or services, or as a compromise between what is given and what is received. Zeithaml (1988) model further classified four different elements of customer value which elaborates "value as low price, value as whatever the consumer wants in product, value as quality obtained from the price paid and lastly value as what consumer gets for what he or she paid.". Zeithaml's model of perceived value has a direct influence on purchase intention (Lundgren, 2013) and it allows for both benefits and sacrifices included in any action that increase customer value (Klanac, 2013). Criticism, However, the difference between the characteristics of the object and higher level concepts does not exists in this theory (Klanac, 2013) as well as being unable to support the sources of value identification and reasons foundations of values provision (Klanac, 2013). Additionally, this model is not tackling the irrational experiences of the customers which is achievable via direct examination of customer activities (Klanac, 2013). However, there are limitations for this model as this resorted to the experience of service due to the multidimensional model defined by conventional aspects such as the perceived benefit, perceived quality, as well as the perceived risk (Moosa \& Hassan, 2015).

HOLBROOK (1999) - Typology of Consumer Value: The theory by Holbrook (1999) labelled perceived value as an interactive relativistic preference experience in the context of comparativeness, subjectivity and specificity. Furthermore, this theory suggests that factors such as play, efficiency, status, excellence, spirituality, aesthetics, esteem, and ethics are values which are individually different where customers may acquire via consumption and these values are categorised according to three dimensions i.e. self- or other-oriented, extrinsic or intrinsic, and active or reactive. This theory is considered as the most complete model in a study by Sanchez-Fernandez \& Iniesta-Bonillo (2007) and this is because it considered more dimensions and aspects such as social, economic, hedonic, and 
selfless aspect. Moreover, this theory also eases in the identification of the value dimensions if the perceived value is based on customers' needs (Aulia, et al., 2016). The idea of this model and framework is based on the product value encompassing goods and services through three-dimensional aspects (Holbrook, 1999). Hence, this theory is deemed as one of the appropriate frameworks in determining customer perceived value (Moosa \& Hassan, 2015). Criticism, However, this theory has a complicated operationalization for certain value elements, for example the ethical and spiritual value which are overlooked and there is ambiguity between elements like status and esteem (Solomon, 1999). Moreover, it is not easy to classify perceived values to differentiate between active and reactive sources.

WOODRUFF (1997) - Consumer Value Hierarchy Model: The theory of Woodruff consists of goals of customers, their consequences as well as product attributes or performance, and incorporating received value and desired value which concentrate on values themselves according to customers' assessments which changes over time. This theory provides insights in understanding the customers' needs instead of benefit-sacrifice method (Woodruff \& Gardial, 1996) which is outstanding in the clarification of the complication of perceived value as well as aids in explaining the reasons behind customers judgements of various benefits in evaluation of different kind of products (Khalifa, 2004). It also redirect the value emphasis from attributes to consequences to yield value for distinct and strategic competitive advantage. Criticism, However, this theory is unable to explain the customer perceived value diversity (Sanchez-Fernandez \& Iniesta-Bonillo, 2007) as well as being incapable to pinpoint the attribute preference of customer values which shaped customer value. This is due to individual preference of every customer regarding the features of the a product (Aulia, et al., 2016).

MONROE (1985) - Price and Quality Model: This theory ascertains the product cost or price perceived by customers as a method in assessing the perceived sacrifice against perceived sacrifice (Animashaun, et al., 2016) which displays significantly positive relationship between perceived quality and perceived price in terms of ranges of price as well as certain genres of product (Venkataraman, 1981).Criticism, However, Monroe fails to incorporate dimensions which evaluate customer perceived value as it comprises merely cost as the culprit in defining customer perceived value (Animashaun, et al., 2016). In addition, Peterson \& Wilson (2000) deduced that the relationship between price and customer perceived quality are not always well defined directly.

\subsection{Research Gap}

As there are no previous study which investigates the impact of customer perceived value on customer purchase intention on the Malaysian housing real estate market, this research aims at filling the void in this context (Karna, et al., 2004; Karna, 2014; Kong, et al., 2015; Lundgren, 2013; Sunthorncheewin, et al., 2013; Yang \& Zhu, 2006). A study was conducted by Lundgren (2013) on the effects of customer perceived value in the context of residential properties by conducting a case study in Sweden. The total sample size is 283 and the overall customer perceived values is the dependent variable. This study investigates the relationship between a number of independent variables e.g. physical functionalities of houses and location attributes. The author employed a structural equation model to analyse and it is revealed that customers expect to be able to relax as well as the feeling of safety in the neighborhood proximity have significant effects on customer perceived value. Results show that properly planned layout as well as the amount of natural daylight have the most significant effects on customer perceived value. Thus, this theory can be used by relevant parties in housing. On the other hand, a study is also conducted by Karna (2014) on the analysis of customer purchase intention as well as satisfaction and construction quality by conducting case study among the private and public customers. Then, data is acquired from external source from Construction Quality Association (RALA), an organisation which offers information about audit which is related Finnish construction and property. Customer satisfaction and purchase decision / intention are the dependent variables. Subsequently, a couple of independent variables such as building and construction qualities, customer experiences and expectations etc. are analysed in terms of relationship among the variables. Then, RALA's feedback system as well as chi-square test are applied to analyse the collected data. Major outcomes of the study showed public customers have lower satisfaction level than private customers on the performance of contractors. Furthermore, contractors have to enhance their level of 
performance by improving quality assurance and enhance the procedures of handover as well as better material so as to increase customer retention level.

In addition, a study conducted by Sunthorncheewin, et al. (2013) in the investigation of customer loyalty via means of customer satisfaction as well as perceived value elements in house purchasing. The total sample size is 253 who mostly buy or own houses and the dependent variables are customer satisfaction and loyalty. The analysis of this study is on the relationship between a number of independent variables e.g. perceived social value, perceived functional value (quality and price), , emotional value and relational value. Furthermore, regression, reliability and factor analyses are among the tools used for analysis in this study. Major outcomes indicated all aspects of customer perceived value in this study show positive significant effects on customer satisfaction and loyalty whereas relational value is revealed as the most significant factor affecting customer satisfaction than the functional value of the product. In the latest study conducted by Chong and Dastane (2017),factors strongly affecting considerations of residential property consumers in Malaysia has been identified as financial, nebhrourhood and location factor which can be classified under functional and social value but relational aspect consideration is not investigated in this research.

Since there are several studies and research of impact of customer perceived value on purchase intention which apply dependent and independent variables adopted from theories by Zeithaml (1988), Woodruff (1997) and Monroe (1985), the Theory of Consumption Value by Sheth et al. (1991) will be adopted in this research as this model was hardly been applied in similar research in the Malaysian residential property context. From the literature review, it can be said that most researchers adopted independent variables from theories such as the perceived quality and value from Zeithaml (1988), Holbrook (1999), and Woodruff (1997) and which they are mostly used in researches and study done by Moosa \& Hassan (2015) and Animashaun et al. (2016), as they are considered to be more appropriate frameworks in evaluating customer perceived value. However, this study adopts Theory of Consumption Value by Sheth et al. (1991) as it is considered to be excellent in analyzing the diverse traits and attributes of products through exploring customers' opinion, which fits the objective of this study. Among the studies conducted in Malaysia on the impact of customer perceived value on consumer's purchase intention includes Nor Asshidin, et al. (2016), Ariffin, et al. (2016), Younus et al. (2015) and Khan, et al. (2010) which focus on respective industrial context such as green products etc. These researches aimed to investigate the products offered by manufacturers and other context but not residential property market, hence, as mentioned earlier, it is the gap that needs to be filled in order to investigate the customer perceived value in the property market. 


\subsection{Research Theoretical Framework}

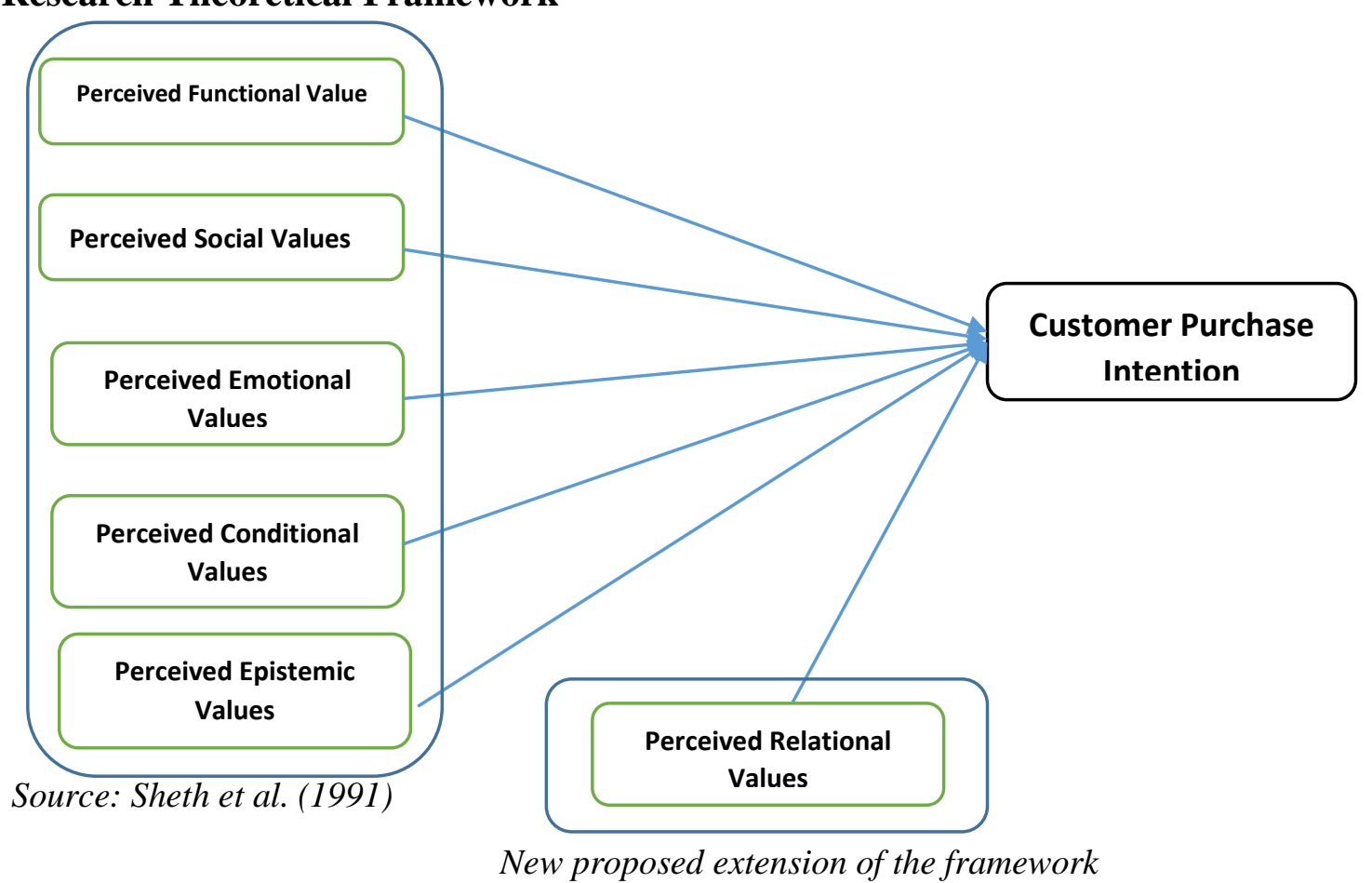

Figure 1: Theoretical Framework

The independent variables adopted from the table above for this research are: Perceived Functional Values - quality, design, price and function etc. of a house. Perceived Social Values social self-concept/good impression enhancement of a house. Perceived Emotional Values - feelings generated from purchasing house. Perceived Relational Values - relationship with housing estate developer in terms of organisational image, conflict, trust and communication. Perceived Conditional Values - perceived benefits gained in the specific situation, physical or social context.Perceived Epistemic Values - perceived benefits that arouse curiosity, satisfy knowledge desire and provide novelty from purchasing house

Karna (2012) and Sunthorncheewin, et al. (2013) stated that the perceived quality of construction and building has an impact on customer purchase intention. Sunthorncheewin, et al. (2013) included social values as one of the customer perceived values in one of the hypotheses related to customer purchase intention in their researches, emotional values as one of the customer perceived values in one of the hypotheses related to customer purchase intention in their researches and relational values is one of the customer perceived values which affect customer purchase intention and included in one of the hypotheses related to customer purchase intention in the research. Haba et al. (2017) presents that conditional value to be the second most important customer perceived value customer during decision making in purchasing products and will affect customer purchase intention as well as loyalty. Awuni \& Du (2015) came up from a study that the search for knowledge is crucial in encouraging decisions of consumers in trial of new products or services. Products related to green and environmental friendly stimulate curiosity and novelty of consumers and a study by Ginsberg \& Bloom (2004) and Biswas \& Roy (2015) justified that the absence of green products affects the buying behaviour and the environmental concern in consumers. Other than that, there were studies concluding that epistemic value has a significant impact on customer purchase behaviour and intention (Lin, et al., 2010; Suki, 2016). Following hypotheses are thus formulated: 


\begin{abstract}
H1: There is positive significant impact of perceived functional values on customer purchase intention in property industry.
\end{abstract}

H2: There is positive significant impact of perceived social values on customer purchase intention in property industry.

H3: There is positive significant impact of perceived emotional values on customer purchase intention in property industry.

H4: There is positive significant impact of perceived relational values on customer purchase intention in property industry.

H5: There is positive significant impact of perceived conditional values on customer purchase intention in property industry.

H5: There is positive significant impact of perceived epistemic values on customer purchase intention in property industry.

\title{
3.0 Research Methodology
}

Research Design: Descriptive and explanatory studies approach are selected in this study where descriptive research is intended to justify current practice and perform assessment in developing theories (Burns \& Grove, 2007). On the other hand, explanatory research is also applied in this study to test and verify hypotheses and justify the developed conceptual framework in the process of investigating the effects and relationship of customer perceived value on their purchase intention as explanatory research is aimed at answering questions on "why" (Burns \& Grove, 2007) and tries to decipher whether relationship between variables is causal through experimentation and understand the nature between causal variables and effect prediction. Research Philosophy: Positivism as a research philosophy is used and the information is collected from the working professionals and businessmen of this generation which is interpreted through reason and logic forms. Quantitative approach is selected for this study with a sample size of maximum of total 200 respondents through a structured survey questionnaire is used for collecting data along with the testing of hypotheses with the purpose of analysing the relationship between the variables (Johnson \& Christensen, 2008). Data Collection Methods, Tools \& Accessibility: Since the collection of data is obtained through distribution of survey questionnaires, both electronically and hard copies, to participants according to certain criteria followed by letter of permission approval, and form of consent of participants are distributed to participants besides distributing the survey questionnaires in order to obtain approval from the participants. Data Instruments: A five-point Likert scale is applied to measure from 1 (Strongly Disagree) to 5 (Strongly Agree) in the questionnaire which requires respondents to fill in.

Total Population and Sample Size: In this study, Selangor state is chosen as the main area, particularly the Klang Valley province which focuses on Petaling Jaya and Subang Jaya. As of 2016, there are a total of 6.3 million populations in Petaling Jaya and 1.41 million populations in Subang Jaya according to Department of Statistics Malaysia (2016). Moreover, the target sample size is 200 with participants who are at least 20 years old and with proper jobs, business (self-employed) or retired. However, the number of sample returned eventually is 172 respondents. Respondents are invited to take part in the survey questionnaire in the form of either electronic form or hard copy questionnaire in this study. On the other hand, this study implements convenience sampling method which direct particular participants based on certain demographical profiles e.g. gender, age, annual income, occupation, marital status, and educational qualification (Samuels, 2013).

Data analysis plan: Demographic analysis is to be done to assess the population size in studying the respondents' details or profiles. Normality test is aimed at assessing the collected data set in terms of the normality where the Skewness and Kurtosis readings have to be within the range of -1 to +1 . Reliability test is to be conducted to assess the collected data set in terms of the internal consistency and data reliability through the use of Cronbach's alpha. Data distribution analysis is aimed at 
analysing the data distribution and behaviour using histogram, P-P plot and Scatter plot. Descriptive statistics analysis is to be conducted to elaborate the details and demographic information as well as providing a summary of the data. Pearson's Correlation Analysis is to be done to investigate the statistical relationship between two continuous variables with values between -1 to +1 indicating positive or negative correlation. Regression analysis is to be used to verify the linear relationship between two variables (dependent and independent) using R Square method

\subsection{Data Analysis}

Through Statistical Package for Social Science (SPSS), systematic analysis is done from collected data to test research hypotheses. The statistical data set collected from 172 respondents will be evaluated with demographic profiles, normality \& regression tests, correlation \& regression analysis to understand the appropriateness of the hypotheses in this research.

\subsection{Demographic Profiles}

Demographic analysis is defined as the analysis of the population size, distribution of regions and population composition of the respondents. Out of the 172 respondents, there are 80 male respondents which form $46.5 \%$ of the total respondents and 92 female respondents which represent $53.5 \%$ of the total respondents. The majority respondents who participated in the survey are of age between 30 to 35 years. The number of single and married respondents who participated in the survey is almost equal. the majority respondents participated in this survey falls in the tertiary education educational qualification with 159 respondents which represented $92.4 \%$ of the total respondents. The first occupation class is business (self-employed) and there are 30 respondents which made up $17.4 \%$ of the total respondents followed by the second occupation of executive and professionals which encompass majority respondents at 124 respondents and $72.1 \%$. The majority of the respondents who participated in this survey comes from executives and professional working levels with majority of the respondents fall under annual income group of RM 70,001 and above. On the other hand, almost all of the respondents taken part in this survey have tertiary education and above. Hence, it can be said that the demographic profiles of the respondents collected are logical and suitable for this context of study.

\subsection{Normality Test}

In this paper, the test method applied for the normality test is D'Agostino's K2 test (a.k.a. skewness and kurtosis analysis) which depends on two factors i.e. kurtosis and skewness in its calculation (D'Agostino, 1970). It is said that the rule of thumb for the values of skewness and kurtosis should be within -1 to +1 ideally (Hair, et al., 2006). Skewness \& Kurtosis values for most of the responses were recorded between -1 to 1 . However, for certain responses skewness \& kurtosis values are found to be in range between -2 to +2 which is still acceptable.

\subsection{Reliability Test}

In this paper, Cronbach's alpha method is applied as it is deemed the most common measure of data consistency and suitable for use when multiple questions using Likert scale are used in a survey or questionnaire in determining its reliability (Laerd Statistics, 2013). In general, the rule of thumb for Cronbach's alpha score interpretation is applied. 
Table 1: Reliability Test - Overall Cronbach's alpha Score

\begin{tabular}{c|c}
\hline Cronbach's alpha & No. of Items \\
\hline 0.904 & 30 \\
\hline
\end{tabular}

Table 2: Reliability Test - Detailed Cronbach's alpha Score

\begin{tabular}{c|c|c}
\hline Variables & Cronbach's alpha & No. of Items \\
\hline Average for all variables & 0.828 & 7 \\
\hline Functional value & 0.528 & 4 \\
\hline Social value & 0.653 & 4 \\
\hline Emotional value & 0.726 & 4 \\
\hline Relational value & 0.813 & 4 \\
\hline Conditional value & 0.615 & 4 \\
\hline Epistemic value & 0.763 & 6 \\
\hline Customer purchase intention & 0.824 &
\end{tabular}

According to Table, the overall reliability score in terms of Cronbach's alpha value of 0.904 based on 30 number of items (4 items in each independent variables and 6 items in dependent variable) produced excellently high reliability and consistency of data (refer to Error! Reference source not found.) and this indicates that all the variables demonstrate good reliability in terms of internal consistency.

\subsection{Data Distribution}

The distribution of statistical data set shows all the possible values (or intervals) of the data and how often they occur. Data Distribution analysis is done through histogram analysis, P-P Plot analysis \& Descriptive statistics analysis in this research. Histogram: The use of histogram enables researchers to investigate the data set by examining the shapes of the distribution which includes normal distribution, outliers, skewness etc. (Laerd Statistics, 2013).

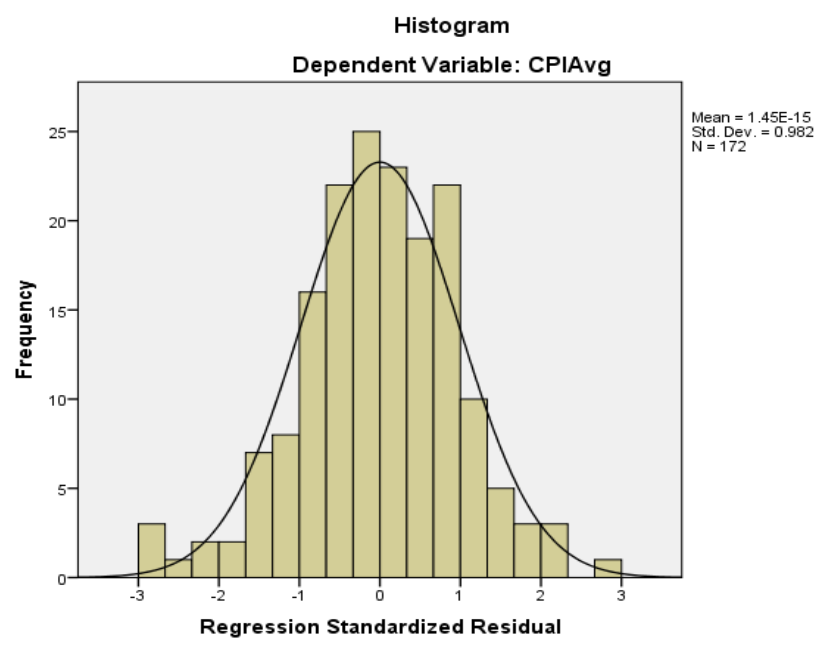

Figure 1: Data Distribution Histogram - Customer Purchase Intention 
Figure 2 displays the data distribution histogram of customer purchase intention. The collected data exhibits a normal distribution judging from the bell-shaped curves where the most of the value are within the bell curve with an overall mean value of $1.45^{-15}$ and standard deviation value of 0.982 . This results indicates that the data set is considered normally distributed. P-P Plot: The purpose of the P-P plot is to aid in determining actual data distribution other than observation of histogram. Results forming a straight diagonal line is desirable as it indicates normal distribution for both theoretical and observed data (Grace-Martin, 2008).

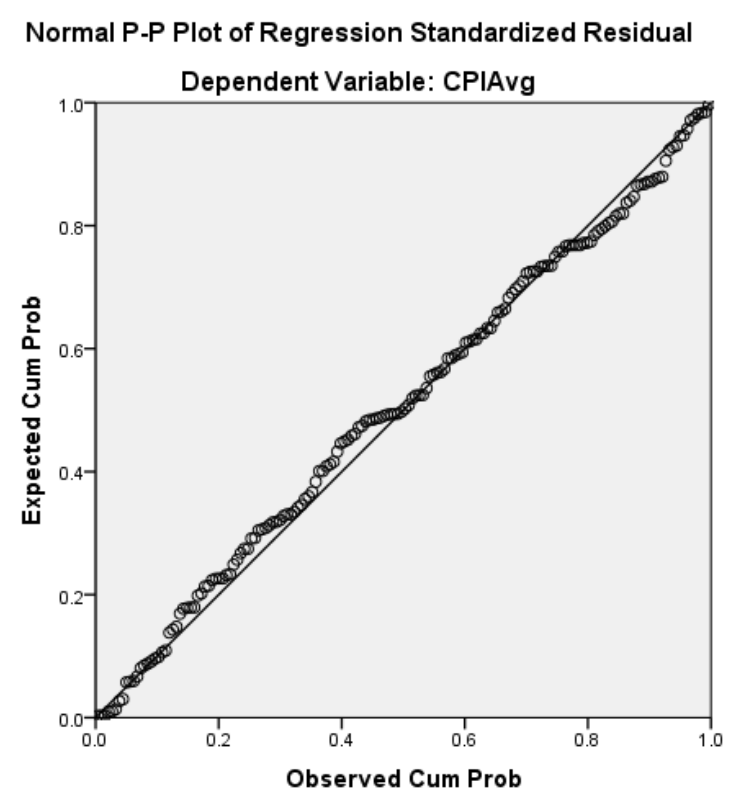

Figure 3: P-P Plot - Customer Purchase Intention

According to

Figure, the P-P plot indicates that the collected data is considered to be normal distribution as every point are located near to or along the regression line. However, slight misalignment is observed somewhere at the mid-point and top-right point but still within tolerance. Descriptive Statistics: Descriptive statistics are commonly used to illustrate the summary of features of a set of data observed in a study which deliver overview and simple summary regarding the data in conjunction with graphical analysis (such as histograms) through quantitative analysis of data (Trochim, 2006)

Table 3: Descriptive Statistics

\begin{tabular}{c|c|c|c}
\hline \multicolumn{4}{c}{ Descriptive Statistics } \\
\hline $\begin{array}{c}\text { Customer Purchase } \\
\text { Intention }\end{array}$ & 3.6987 & .62187 & 172 \\
\hline Functional Value & 4.3547 & .48886 & 172 \\
\hline Social Value & 3.4695 & .75230 & 172 \\
\hline Emotional Value & 4.0000 & .66995 & 172 \\
\hline Relational Value & 4.0552 & .66875 & 172 \\
\hline Conditional Value & 4.0494 & .61928 & 172 \\
\hline Epistemic Value & 3.7166 & .75314 & 172 \\
\hline
\end{tabular}


From the mean values, it can be said that the link between functional value and customer purchase intention is observed to be strongest (due to higher overall mean scores) which indicates most customers perceive functional value to be the most important in shaping the purchase intention compared to relational, conditional and epistemic value while social value is the least considered.

\subsection{Pearson's Correlation Analysis}

Correlation analysis is a method or procedure for investigating the statistical relationship between two continuous variables and their level of association in certain population which is commonly denoted by r, a figure as the Pearson's correlation coefficient (van den Berg, 2014). In this study, a 2-tailed test of significance and bivariate method are applied.3

Table 4: Degree of Correlation Coefficient

Coefficient, $r$

\begin{tabular}{c|c|c}
\hline Strength of Association & Positive & Negative \\
\hline Small / Weak & 0.1 to 0.3 & -0.1 to -0.3 \\
\hline Medium / Moderate & 0.3 to 0.5 & -0.3 to -0.5 \\
\hline Large / Strong & 0.5 to 1.0 & -0.5 to -1.0 \\
\hline
\end{tabular}

(Laerd Statistics, 2013)

On the other hand, the p-value which is denoted by "sig. (2-tailed)" in the correlation table from SPSS indicates the probability of that particular value of $r$ and it is said that smaller $p$-value is the desired result and ideally smaller than 0.05 or 0.01 (van den Berg, 2014).

Table 5: Pearson's Correlation Analysis

\begin{tabular}{|c|c|c|c|c|c|c|c|c|}
\hline \multicolumn{9}{|c|}{ Correlations } \\
\hline & & $\begin{array}{l}\text { Function } \\
\text { al Value }\end{array}$ & $\begin{array}{l}\text { Social } \\
\text { Value }\end{array}$ & $\begin{array}{l}\text { Emotion } \\
\text { al Value }\end{array}$ & $\begin{array}{l}\text { Relation } \\
\text { al Value }\end{array}$ & $\begin{array}{c}\text { Conditio } \\
\text { nal } \\
\text { Value }\end{array}$ & $\begin{array}{c}\text { Epistemi } \\
\text { c Value }\end{array}$ & \begin{tabular}{|c|} 
Custome \\
$\mathbf{r}$ \\
Purchase \\
Intention \\
\end{tabular} \\
\hline \multirow{3}{*}{$\begin{array}{c}\text { Functional } \\
\text { Value }\end{array}$} & $\begin{array}{l}\text { Pearson } \\
\text { Correlation }\end{array}$ & 1 & $.229^{* *}$ & $.427^{* *}$ & $.385^{* *}$ & $.382^{* *}$ & $.320^{* *}$ & $.429^{* * *}$ \\
\hline & Sig. (2-tailed) & & .002 & .000 & .000 & .000 & .000 & .000 \\
\hline & $\mathrm{N}$ & 172 & 172 & 172 & 172 & 172 & 172 & 172 \\
\hline \multirow{3}{*}{$\begin{array}{l}\text { Social } \\
\text { Value }\end{array}$} & \begin{tabular}{|l} 
Pearson \\
Correlation
\end{tabular} & $.229^{* *}$ & 1 & $.347^{* * *}$ & $.271^{* *}$ & $.193^{*}$ & $.282^{* *}$ & $.337^{* *}$ \\
\hline & \begin{tabular}{|l|} 
Sig. (2-tailed) \\
\end{tabular} & .002 & & .000 & .000 & .011 & .000 & .000 \\
\hline & $\mathrm{N}$ & 172 & 172 & 172 & 172 & 172 & 172 & 172 \\
\hline \multirow{3}{*}{$\begin{array}{c}\text { Emotional } \\
\text { Value }\end{array}$} & $\begin{array}{l}\text { Pearson } \\
\text { Correlation }\end{array}$ & $.427^{* *}$ & $.347^{* *}$ & 1 & $.538^{* *}$ & $.474^{* *}$ & $.517^{* *}$ & $.492^{* *}$ \\
\hline & Sig. (2-tailed) & .000 & .000 & & .000 & .000 & .000 & .000 \\
\hline & $\mathrm{N}$ & 172 & 172 & 172 & 172 & 172 & 172 & 172 \\
\hline \multirow{3}{*}{$\begin{array}{l}\text { Relational } \\
\text { Value }\end{array}$} & \begin{tabular}{|l|} 
Pearson \\
Correlation \\
\end{tabular} & $.385^{* *}$ & $.271^{* *}$ & $.538^{* *}$ & 1 & $.514^{* *}$ & $.435^{* *}$ & $.520^{* *}$ \\
\hline & Sig. (2-tailed) & .000 & .000 & .000 & & .000 & .000 & .000 \\
\hline & $\mathrm{N}$ & 172 & 172 & 172 & 172 & 172 & 172 & 172 \\
\hline \multirow{3}{*}{$\begin{array}{l}\text { Conditional } \\
\text { Value }\end{array}$} & \begin{tabular}{|l|} 
Pearson \\
Correlation \\
\end{tabular} & $.382^{* *}$ & $.193^{*}$ & $.474^{* *}$ & $.514^{* *}$ & 1 & $.529^{* *}$ & $.557^{* *}$ \\
\hline & \begin{tabular}{|l} 
Sig. (2-tailed) \\
\end{tabular} & .000 & .011 & .000 & .000 & & .000 & .000 \\
\hline & $\mathrm{N}$ & 172 & 172 & 172 & 172 & 172 & 172 & 172 \\
\hline
\end{tabular}




\begin{tabular}{c|l|r|r|r|r|r|r|r}
\hline \multirow{3}{*}{$\begin{array}{c}\text { Epistemic } \\
\text { Value }\end{array}$} & $\begin{array}{l}\text { Pearson } \\
\text { Correlation }\end{array}$ & $.320^{* *}$ & $.282^{* *}$ & $.517^{* *}$ & $.435^{* *}$ & $.529^{* *}$ & 1 & $.563^{* *}$ \\
\cline { 2 - 9 } & Sig. (2-tailed) & .000 & .000 & .000 & .000 & .000 & & .000 \\
\cline { 2 - 8 } & $\mathrm{N}$ & 172 & 172 & 172 & 172 & 172 & 172 & 172 \\
\hline \multirow{2}{*}{$\begin{array}{c}\text { Customer } \\
\text { Purchase } \\
\text { Intention }\end{array}$} & $\begin{array}{l}\text { Pearson } \\
\text { Correlation }\end{array}$ & $.429^{* *}$ & $.337^{* *}$ & $.492^{* *}$ & $.520^{* *}$ & $.557^{* *}$ & $.563^{* *}$ & 1 \\
\cline { 2 - 8 } & Sig. (2-tailed) & .000 & .000 & .000 & .000 & .000 & .000 & \\
\cline { 2 - 8 } & $\mathrm{N}$ & 172 & 172 & 172 & 172 & 172 & 172 & 172 \\
\hline
\end{tabular}

**. Correlation is significant at the 0.01 level (2-tailed).

*. Correlation is significant at the 0.05 level (2-tailed).

Table 6: Simplified Correlation Value

\begin{tabular}{l|l|l}
\hline Perceived Value & Correlation $(\mathbf{r})$ & Significance $(\mathbf{p}<\mathbf{0 . 0 5})$ \\
\hline Functional Value $\leftarrow \rightarrow$ CPI & Moderate, Positive $(0.429)$ & 0.000 \\
\hline Social Value $\leftarrow \rightarrow$ CPI & Moderate, Positive $(0.337)$ & 0.000 \\
\hline Emotional Value $\leftarrow \rightarrow$ CPI & Moderate, Positive $(0.492)$ & 0.000 \\
\hline Relational Value $\leftarrow \rightarrow$ CPI & Strong, Positive $(0.520)$ & 0.000 \\
\hline Conditional Value $\leftarrow \rightarrow$ CPI & Strong, Positive $(0.557)$ & 0.000 \\
\hline Epistemic Value $\leftarrow \rightarrow$ CPI & Strong, Positive $(0.563)$ & 0.000 to 0.0002 \\
\hline
\end{tabular}

The above correlation analysis reveals that all the perceived values have significant positive correlation with the customer perceived intention. Relational, Conditional \& Epistemic values are found to have strong significant positive correlation with customer purchase intention whereas Functional, social \& emotional values are found to have moderate significant positive correlation with customer purchase intention.

\subsection{Regression Analysis}

Regression analysis is implemented in this statistical research for verifying the linear relationship between two variables (dependent and independent) and above and it is mainly applied in predictive analysis (Campbell \& Campbell, 2008). Model Summary: R-squared is measured to determine the closeness of data to the fitted regression line in regression analysis and the value of Rsquared is always between 0 to $100 \%$ (or 0 to 1) (Frost, 2013). Besides, Durbin-Watson value will be analysed in the regression where it is a test statistic used to detect autocorrelation in a regression analysis and the value is always between 0 and 4 . Value of 2 corresponds to no autocorrelation in the data set and values near to 0 will mean positive auto correlation while values close to 4 indicate negative correlation (Durbin \& Watson, 1950).

Table 7: Model Summary

\begin{tabular}{|c|c|c|c|c|c|c|c|c|c|c|}
\hline \multicolumn{11}{|c|}{ Model Summary } \\
\hline \multirow[b]{2}{*}{ Model } & \multirow[b]{2}{*}{$\mathbf{R}$} & \multirow[b]{2}{*}{ R Square } & \multirow[b]{2}{*}{$\begin{array}{l}\text { Adjusted } \\
\text { R Square }\end{array}$} & \multirow[b]{2}{*}{$\begin{array}{l}\text { Std. Error of } \\
\text { the Estimate }\end{array}$} & \multicolumn{5}{|c|}{ Change Statistics } & \multirow[b]{2}{*}{$\begin{array}{l}\text { Durbin- } \\
\text { Watson }\end{array}$} \\
\hline & & & & & \begin{tabular}{|c}
$\mathbf{R}$ \\
Square \\
Chang \\
e
\end{tabular} & $\begin{array}{c}\text { F } \\
\text { Chang } \\
\text { e }\end{array}$ & df1 & df2 & $\begin{array}{l}\text { Sig. F } \\
\text { Chang } \\
\text { e }\end{array}$ & \\
\hline 1 & $.701^{\mathrm{a}}$ & .491 & .473 & .45148 & .491 & 26.570 & 6 & 165 & .000 & 2.081 \\
\hline
\end{tabular}

a. Predictors: (Constant), Epistemic Value, Social Value, Functional Value, Relational Value, Conditional Value, Emotional Value

b. Dependent Variable: Customer Purchase Intention 


\begin{tabular}{|c|c|c|c|c|c|c|c|c|c|c|}
\hline \multicolumn{11}{|c|}{ Model Summaryb } \\
\hline \multirow[b]{2}{*}{ Model } & \multirow[b]{2}{*}{$\mathbf{R}$} & \multirow[b]{2}{*}{ R Square } & \multirow[b]{2}{*}{$\begin{array}{l}\text { Adjusted } \\
\text { R Square }\end{array}$} & \multirow[b]{2}{*}{$\begin{array}{l}\text { Std. Error of } \\
\text { the Estimate }\end{array}$} & \multicolumn{5}{|c|}{ Change Statistics } & \multirow[b]{2}{*}{$\begin{array}{l}\text { Durbin- } \\
\text { Watson }\end{array}$} \\
\hline & & & & & \begin{tabular}{|c|}
$\mathbf{R}$ \\
Square \\
Chang \\
e \\
\end{tabular} & $\begin{array}{c}\text { F } \\
\text { Chang } \\
\text { e }\end{array}$ & df1 & df2 2 & $\begin{array}{l}\text { Sig. F } \\
\text { Chang } \\
\quad \text { e }\end{array}$ & \\
\hline 1 & $.701 \mathrm{a}$ & .491 & .473 & .45148 & .491 & 26.570 & 6 & 165 & .000 & 2.081 \\
\hline
\end{tabular}

a. Predictors: (Constant), Epistemic Value, Social Value, Functional Value, Relational Value, Conditional Value, Emotional Value

b. Dependent Variable: Customer Purchase Intention

which shows the summary of regression model, the R Square value is 0.491 which indicates $49.1 \%$ of the Customer Purchase Intention is able to be predicted by the independent variables. In addition, the adjusted $\mathrm{R}$ Square value is 0.473 which indicates that the model is deemed not a good fit model owing to the fact that the adjust $\mathrm{R}$ Square value is less than 0.60 (the minimum requirement to be a good fit model) (Hair, et al., 2006). On the other hand, the Durbin-Watson value of 2.081 which is close to value of 2 indicates no autocorrelation. This leads to the fact that there is zero conflict and autocorrelation among the respondents (Laerd Statistics, 2013).

Table 8: Coefficients

\begin{tabular}{|c|c|c|c|c|c|c|}
\hline & \multicolumn{6}{|c|}{ Coefficients $^{\mathrm{a}}$} \\
\hline & \multirow[t]{2}{*}{ Model } & \multicolumn{2}{|c|}{$\begin{array}{c}\text { Unstandardized } \\
\text { Coefficients }\end{array}$} & \multirow{2}{*}{$\begin{array}{c}\begin{array}{c}\text { Standardized } \\
\text { Coefficients }\end{array} \\
\text { Beta } \\
\end{array}$} & \multirow[t]{2}{*}{$\mathbf{t}$} & \multirow[t]{2}{*}{ Sig. } \\
\hline & & B & Std. Error & & & \\
\hline \multirow[t]{7}{*}{1} & (Constant) & -.009 & .343 & & -.026 & .979 \\
\hline & $\begin{array}{l}\text { Functional } \\
\text { value }\end{array}$ & .179 & .081 & .141 & 2.207 & .029 \\
\hline & Social value & .101 & .050 & .122 & 2.026 & .044 \\
\hline & $\begin{array}{l}\text { Emotional } \\
\text { value }\end{array}$ & .050 & .069 & .054 & .719 & .473 \\
\hline & $\begin{array}{l}\text { Relational } \\
\text { value }\end{array}$ & .162 & .066 & .174 & 2.434 & .016 \\
\hline & $\begin{array}{l}\text { Conditional } \\
\text { value }\end{array}$ & 228 & .072 & .227 & 3.152 & .002 \\
\hline & Epistemic value & .215 & .059 & .260 & 3.668 & .000 \\
\hline
\end{tabular}

a. Dependent Variable: Customer Purchase Intention

\subsection{Summary of Key Findings}

Table 9: Summary of Hypotheses

\begin{tabular}{l|c|c|c}
\hline \multicolumn{1}{c|}{ Hypothesis } & $\begin{array}{c}\text { Beta } \\
\text { Coefficient }\end{array}$ & $\begin{array}{c}\text { Significance } \\
\text { Value } \\
(\mathbf{p}<\mathbf{0 . 0 5})\end{array}$ & Results \\
\hline $\begin{array}{l}\text { H1: "There is positive significant impact of perceived } \\
\text { functional values on customer purchase intention in } \\
\text { property industry" }\end{array}$ & 0.141 & 0.029 & Accepted \\
\hline $\begin{array}{l}\text { H2: "There is positive significant impact of perceived social } \\
\text { values on customer purchase intention in property industry" }\end{array}$ & 0.122 & 0.044 & Accepted \\
\hline
\end{tabular}




\begin{tabular}{l|l|l|l}
\hline $\begin{array}{l}\text { H3: "There is positive significant impact of perceived } \\
\text { emotional values on customer purchase intention in } \\
\text { property industry" }\end{array}$ & 0.054 & 0.473 & Rejected \\
\hline $\begin{array}{l}\text { H4: "There is positive significant impact of perceived } \\
\text { relational values on customer purchase intention in property } \\
\text { industry" }\end{array}$ & 0.174 & 0.016 & Accepted \\
\hline $\begin{array}{l}\text { H5: "There is positive significant impact of perceived } \\
\text { conditional values on customer purchase intention in } \\
\text { property industry" }\end{array}$ & 0.227 & 0.002 & Accepted \\
\hline $\begin{array}{l}\text { H6: "There is positive significant impact of perceived } \\
\text { epistemic values on customer purchase intention in property } \\
\text { industry" }\end{array}$ & 0.260 & 0.000 & Accepted \\
\hline
\end{tabular}

The demographic profile shows that the research datasets was well distributed with convenience sampling technique and sample size of 172 respondents. Normality test is carried out and the sample fits the standard normal distribution. The Cronbach's alpha showed the reliability of the data which was reliable and acceptable for a research study from 0.589 to 0.90 (George \& Mallery, 2003; Hair et al. 2010), none of the constructs were below 0.52. In order to find the distribution of statistical data, Histogram, P-P Plot, Scatter Plot and Descriptive Statistics analysis have been done. Pearson Correlation analysis is used to evaluate the linear relationship between the independent and dependent variable from which the strength of the association is found to be positive, significant \& moderate to strong. Relational Value, Conditional Value \& Epistemic Value is found to be strongly correlated with the Customer Purchase Intention than the other perceived values. Prediction of the consumer perception and its impact on purchase intention is done using the simple linear regression technique in this study.

\subsection{Conclusion}

Relational value has emerged as one of the important dimensions of customer perceived value for residential property market and emotional value doesn't seem to be significant. This justifies the extension of Seth el al, 1991 model for the property market by including relational value dimension. Conditional Value \& Epistemic value are also found to have very high effect on Customer Purchase Intention. Hence, the analysis of the research is used to identify the perceived values that might have impacted the customer purchase intention of residential property market by answering the research question and objectives and by determining the actual perceived value dimensions influencing customer purchase intention of residential property market. Thus the research contributes academically to the existing literature.

Practically, this study suggests that property developers should enrich the functional aspects of their products i.e. residential houses (such as practical space planning and innovative architectural design) as well as further promote their residential properties through innovative marketing activities. This is in order to boost and fulfil customers' approval and their general understanding of the functional value of the new residential properties along with the development of an optimistic attitude, intention to purchase and their actual purchase behaviour. Such enhancements will enable property developers in generating positive significant purchase intention from customers. It is suggested that the marketers of the property developer should refine and enhance their rebates and overall package of properties as well as improving and maintaining good workmanship so that customers' perception towards developer is further improved. Thus, it appears evident that consumers' awareness is imperative in generating customer purchase intention by means of promotions in terms of the functional and conditional values such as offering various promotions with perks like subsidies and rebates to the customers in order to improve both functional and relational values and consumers' value perceptions of the property developers. On the other hand, it is equally important that the property developers in taking actions regarding customer loyalty and commitment in the relationship by making sure every staff gives their full commitment in providing quality services to the customers so that the customers' perception on the property developers is good and are willing to commit in their 
relationship with the developers, in turns lead to higher purchase intention. Hence, it is essential for developers to constantly maintain good communication and the level of confidence such as maintain honesty, offering accurate information, maintain integrity with the customers. This is so that the perceived relational value of the customers is increased with high purchase intention.

On epistemic value, green marketing can be utilised in their marketing strategies through capturing customers' consciousness on environmental in order to differentiate their products and make place in the green market. This can be done through creative marketing in emphasizing the environmental friendly features to improve purchase intention for the range of consumers with green concept and consciousness by utilising ways to change their products presentation and promoting green housing awareness to improve environmental awareness. Consumers with environmental awareness prefer to buy houses which is designed to conserve natural resources or houses which benefit the environment. Property developers are recommended to establish residential housing projects with green features and aim to become the leading developers in green housing for improved image through building environmental-friendly houses. Through these housing projects, it will also be influential to relatives of potential purchasers. As the limitation, generalization of the results might contain inaccuracies considering the sample taken from just one district of Malaysia. For future Research, It is suggested that a cross culture approach should be applied as the scope of future research to include respondents from the entire Malaysia from east to west to acquire more demographic profiles and to diversify them through targeting respondents from different background in the same industry in order to generate genuine data and relationship between the variables for constructing a better conceptual framework. Moreover, different theory can also be applied in the conceptual framework in future research. 


\section{References}

Animashaun, A., Tunkarimu, T. I. \& Dastane, O., 2016. Customer Perceived Value Towards Convenience Stores in Malaysia: The Influence on Customer Satisfaction, Loyalty and Retention. Journal of Marketing and Consumer Behaviour in Emerging Markets, 2(4), pp. 4-27.

Ariffin, S., Mohd Yusof, J., Putit, L. \& Azalan Shah, M. I., 2016. Factors Influencing Perceived Quality and Repurchase Intention Towards Green Products. Procedia Economics and Finance, Volume 37, pp. 391-396.

Aulia, S. A., Sukati, I. \& Sulaiman, Z., 2016. A Review: Customer Perceived Value and its Dimension. Asian Journal of Social Sciences and Management Studies, 3(2), pp. 150-162.

Awuni, J. A. \& Du, J., 2015. Sustainable consumption in Chinese cities: Green purchasing intentions of young adults based on the theory of consumption values. Sustainable Development, Volume 24, pp. 124-135.

Biswas, A. \& Roy, M., 2015. Leveraging factors for sustained green consumption behaviour based on consumption value perceptions: Testing the structural model. Journal of Cleaner Production, Volume 95, pp. 332-340.

Burns, N. \& Grove, S. K., 2007. Understanding Nursing Research: Building an Evidence-based Practice. 4th ed. s.l.:Saunders Elsevier.

Campbell, D. \& Campbell, S., 2008. Introduction to Regression and Data Analysis. Statlab Workshop, pp. 2-14. Candan, B., Ünal, S. \& Erciş, A., 2013. Analysing the relationship between consumption values and brand loyalty of young people: A study on personal care products. European Journal of Research on Education, pp. 29-46.

Chi, H., Yeh, H. R. \& Tsai, Y. C., 2011. The Influences of Perceived Value on Consumer Purchase Intention: The Moderating Effect of Advertising Endorser.

Choi, E. J. \& Kim, S.-H., 2013. The Study of the Impact of Perceived Quality and Value of Social Enterprises on Customer Satisfaction and Re-Purchase Intention. International Journal of Smart Home , 7(1), pp. 239-252.

Chong, P. H. \& Dastane , O., 2017. Buying a Dream Home - Considerations of Residential Property Consumers in Malaysia. Singaporean Journal of Business, Economics and Management Studies, 5 (9), 19-35

D'Agostino, R. B., 1970. Transformation to normality of the null distribution of g1. s.1.:s.n.

Department of Statistics Malaysia, 2016. Population Quick Info. [Online] Available at: http://www.dosm.gov.my/v1/

[Accessed 13 March 2017].

Durbin, J. \& Watson, G. S., 1950. Testing for Serial Correlation in Least Squares Regression, I. Biometrika, 37(3-4), pp. 409-428.

Fassou Haba, H., Hassan, Z., Dastane, O. (2017). Factors Leading to Consumer Perceived Value of Smartphones and its Impact on Purchase Intention. Global Business and Management Research: An International Journal, 9(1), 42-71.

Frost, J., 2013. Regression Analysis: How Do I Interpret R-squared and Assess the Goodness-of-Fit?. [Online] Available at: http://blog.minitab.com/blog/adventures-in-statistics-2/regression-analysis-how-do-i-interpret-rsquared-and-assess-the-goodness-of-fit

[Accessed 11 January 2018].

Grace-Martin, K., 2008. Anatomy of a Normal Probability Plot. [Online] Available at: https://www.theanalysisfactor.com/anatomy-of-a-normal-probability-plot/ [Accessed 10 January 2018].

George, D. \& Mallery, P., 2010. SPSS for Windows Step by Step: A Simple Guide and Reference, 17.0 Update. 10th ed. Boston: Pearson.

Hair, Anderson, Tatham \& Black, C. W., 2006. Multivariate Data Analysis (5). New Jersey: Prentice Hall.

Holbrook, M.B. ed., 1999. Consumer value: a framework for analysis and research. Psychology Press.

Howard, J.A. and Sheth, J.N., 1969. The theory of buyer behavior (No. 658.834 H6).

Ilieska, K., 2009. Services marketing. macedonian "Marketing na uslugi”, Bitola.

Karna, S., 2014. Analysing customer satisfaction and quality in construction - the case of public and private customers. Nordic journal of surveying and real estate research, Volume 2.

Karna, S., Junnonen, J. \& Kankainen, J., 2004. Customer Satisfaction In Construction. s.1., s.n.

Kaur, M., 2017. Property market will be badly hit in 2018, says expert. [Online] Available at: http://www.freemalaysiatoday.com/category/nation/2017/11/14/property-market-will-be-badly-hitin-2018-says-expert/

[Accessed 11 January 2018].

Khan, N., 2010. FUNCTIONAL AND RELATIONAL VALUE INFLUENCE ON COMMITMENT AND FUTURE INTENTION: THE CASE OF BANKING INDUSTRY. The Journal of International Social Research, 3(10), pp. 377-391. 
Khan, N., Kadir, S. L. S. A. \& Wahab, S. A., 2010. Investigating Structure Relationship from Functional and Relational Value to Behavior Intention: The Role of Satisfaction and Relationship Commitment.. International Journal of Business and Management, 5(10), pp. 20-36.

Klanac, N. G., 2013. An Integrated Approach to Customer Value: A Comprehensive - Practical Approach. J Bus Mark Manag, 6(1), pp. 22-37.

Kong, Y., Glascock, J. L. \& Lu-Andrews, R., 2015. An Investigation into Real Estate Investment and Economic Growth in China: A Dynamic Panel Data Approach. Connecticut: Center for Real Estate and Urban Economic Studies, University of Connecticut.

Laerd Statistics, 2013. Cronbach's Alpha $(\alpha)$ using SPSS Statistics. [Online] Available at: https://statistics.laerd.com/spss-tutorials/cronbachs-alpha-using-spss-statistics.php [Accessed 10 January 2018].

Lim, S., 2016. How Does the Economy Affect the Malaysia Housing Market?. [Online] Available at: https://www.rapidpropertyconnect.com/how-does-the-economy-affect-the-malaysia-housingmarket/

[Accessed 10 November 2017].

Lima, L. P., Miron, L. I. G. M., Leite, F. \& Formoso, C. T., 2009. Perceived Value in Social Housing Projects. s.l., s.n.

Lin, P., Huang, Y. \& Wang, J., 2010. Applying the Theory of Consumption Values to Choice Behavior toward Green Products. International Conference on Management of Innovation \& Technology, pp. 348-353.

Lundgren, B., 2013. Customer-perceived Value in Residential Developments: the Case of Hornsberg Strand, Sweden. International Real Estate Review, 16(1), pp. 1-27.

Mahalingam, E., 2017. Malaysian property prices remain steady. [Online] Available at: https://www.thestar.com.my/business/business-news/2017/04/19/property-prices-remain-steady/ [Accessed 20 November 2017].

Monroe, K.B., 1979. Pricing: Making profitable decisions (pp. 37-46). New York: McGraw-Hill.

NAPIC, 2017. National Property Information Centre: Key Statistic. [Online] Available at: http://napic.jpph.gov.my/portal/web/guest/key-statistics

[Accessed 30 October 2017].

Nor Asshidin, N. H., Abidin, N. \& Borhan, H. B., 2016. Perceived quality and emotional value that influence consumer's purchase intention towards American and local products. Procedia Economics and Finance, Volume 35, pp. 639-643.

Oliver, R. L., 1992. An Investigation of the Attribute Basis of Emotion and Related Affects in Consumption: Suggestions for a Stage-Specific Satisfaction Framework. In: J. F. Sherry \& B. Sternthal, eds. Advances in Consumer Research. Ann Arbor: Association for Consumer Research, pp. 237-244.

Oliver, R. L., 1997. Satisfaction: A behavioral perspective on the consumer. New York: Irwin/McGraw-Hill.

Ong, T. S., 2013. Factors Affecting the Price of Housing in Malaysia. Journal of Emerging Issues in Economics, Finance and Banking, 1(5), pp. 414-429.

Peterson, R. A. \& Wilson, R. W., 2000. Perceived Risk and Price Reliance Scheme and price-Perceived Quality Mediators. In: J. Jacoby \& J. Olson, eds. Perceived Quality. s.1.:Lexington Books, pp. 247-268.

Roy, R. \& Cochrane, S. P., 1999. Development of a customer focused strategy in speculative house building. Construction Management \& Economics, 17(6), pp. 777-787.

Salem Khalifa, A., 2004. Customer value: a review of recent literature and an integrative configuration. Management decision, 42(5), pp.645-666.

Samuels, P., 2013. Statistical Methods - 13 Sampling Techniques. encouraging academics to share statistics support resources.

Sanchez-Fernandez, R. \& Iniesta-Bonillo, M. A., 2007. The concept of perceived value: A systematic review of the research. Marketing Theory, 7(4), pp. 427-451.

Sheth, J. N., Newman, B. L. \& Gross, B. L., 1991. Why We Buy What We Buy a Theory of Consumer Behaviour. Journal of Business Research, 22(2), pp. 159-170.

Sim, J. \& Wright, C., 2000. Research in Health Care. London: Stanley Thomas (Publishers) Ltd.

Solomon, M. R., 1999. The value of status and the status of value. In: M. B. Holbrook, ed. Consumer value. A framework for analysis and research. London: Routledge, pp. 63-84.

Suki, N. M., 2016. Consumer environmental concern and green product purchase in Malaysia: Structural effects of consumption values. Journal of Cleaner Production, Volume 132, pp. 204-214.

Sunthorncheewin, S., Panichpathom, S., Ngarmyarn, A. \& Ratanaprichavej, N., 2013. Investigating Home Buyer Loyalty through Satisfaction and Perceived Value Dimensions. International Journal of Scientific and Research Publications, 3(12), pp. ISSN 2250-3153.

Thean, L. C., 2017. Rebalancing the housing market. [Online] Available at: https://www.thestar.com.my/business/business-news/2017/07/01/rebalancing-the-housing-market/ [Accessed 30 October 2017]. 
$\begin{array}{llllll}\text { Trochim, } & \text { W. } & \text { M. } & \text { K. } & 2006 . & \text { Reliability. }\end{array}$ Available at: $\quad$ http://www.socialresearchmethods.net/kb/reliable.php [Accessed 10 January 2018].

Tung, Z. C. \& Albert, R., 1994. Prices, Product information, and purchase intention: An empirical study. J. Acad. Mark. Sci., 22(1), pp. 16-27.

Van den Berg, R. G., 2014. SPSS Correlation Test - Simple Tutorial. [Online] Available at: https://www.spss-tutorials.com/spss-correlation-test/ [Accessed 11 January 2018].

Venkataraman, V. K., 1981. The price-quality relationship in an experimental setting. Journal of Advertising Research, 21(4), pp. 49-52.

Woodruff, R. B., 1997. Customer value: The next source for competitive advantage. Journal of the Academy of Marketing Science, 25(2), pp. 139-153.

Woodruff, R. B. \& Gardial, S. F., 1996. Know Your Customer: New Approaches to Understanding Customer Value and Satisfaction. Cambridge, MA: Blackwell Publishing Ltd.

Yamamoto, A. P. D. G. T., 2007. Understanding customer value concept: Key to success. Istanbul: Maltepe University.

Yang, D.-J., Wu, J. M. \& Wang, K.-I., 2010. Relationship Quality, Relationship Value, Purchasing Intention: An Empirical Study in the Retail Industry in the USA, Japan and Taiwan. Asian Journal of Arts and Sciences, 1(2), pp. 155-166.

Yang, S. \& Zhu, Y., 2006. Customer Satisfaction Theory Applied in the Housing Industry: An Empirical Study of Low-Priced Housing in Beijing. Tsinghua Science and Technology, 11(6), pp. 667-674.

Yeung, M. C. H., Ging, L. C. \& Ennew, C. T., 2002. Customer satisfaction and profitability: A reappraisal of the nature of the relationship. Journal of Targeting, 11(1), pp. 24-33.

Younus, S., Rasheed, F. \& Zia, A., 2015. Identifying the Factors Affecting Customer Purchase Intention. Global Journal of Management and Business Research: An Administration and Management, 15(2), pp. 9-13.

Zeithaml, V., 1988. Consumer perceptions of price, quality, and value: A means-end model. Journal of Marketing, 52(3), pp. 2-22. 